\title{
Pathogenic and Genetic Variation in the Japanese Strains of Fusarium oxysporum f. sp. melonis
}

\author{
Fumio Namiki, Toshiki Shiomi, Kazufumi Nishi, Tsuruo Kayamura, and Takashi Tsuge
}

First, second, third, and fourth authors: Kyushu National Agricultural Experiment Station, 2421 Suya, Nishigoshi-Machi, Kikuchi-Gun, Kumamoto 861-1192, Japan; fifth author: Graduate School of Bioagricultural Sciences, Nagoya University, Chikusa, Nagoya 464-8601, Japan.

Current addresses of T. Shiomi and T. Kayamura: National Agricultural Research Center, 3-1-1 Kan-nondai, Tsukuba, Ibaragi 305-8666, Japan, and Kumamoto Prefecture Agricultural Research Center, 3801 Sakae, Koshi-Machi, Kikuchi-Gun, Kumamoto 861-1113, Japan.

Accepted for publication 22 April 1998.

\begin{abstract}
Namiki, F., Shiomi, T., Nishi, K., Kayamura, T., and Tsuge, T. 1998. Pathogenic and genetic variation in the Japanese strains of Fusarium oxysporum f. sp. melonis. Phytopathology 88:804-810.

Pathogenic variation among 41 Japanese strains of Fusarium oxyspor$u m \mathrm{f}$. sp. melonis was analyzed by pathogenicity tests with muskmelon, oriental melon, and oriental pickling melon cultivars. Based on pathogenicity to muskmelon cvs. Amus and Ohi and oriental melon cv. Ogon 9, 41 strains were divided into 3 groups that corresponded completely to Risser's races 0,2 , and 1,2y. To further characterize pathogenic variation within the forma specialis and races, strains were assayed for pathogenicity to 42 additional muskmelon, oriental melon, and oriental pickling melon cultivars. All strains of race 1,2y were pathogenic to all cultivars

tested. Strains of race 0 were divided into six variants based on differences in pathogenicity to three muskmelon cultivars; strains of race 2 also were classified into six variants based on differences in pathogenicity to two muskmelon cultivars and one oriental melon cultivar. Genetic variation among strains was analyzed by DNA fingerprinting with four repetitive DNA sequences: FOLR1 to FOLR4. Thirty-six fingerprint types were detected among forty-one strains by pooling results of fingerprinting with four probes. Cluster analysis showed distinct genetic groups correlated with races: the fingerprint types detected in each of races 2 and $1,2 \mathrm{y}$ were grouped into a single cluster, and two distinct genetic groups were found in race 0 . However, pathogenic variation detected within races 0 and 2 could not be differentiated based on the nuclear markers examined.
\end{abstract}

Fusarium oxysporum Schlechtend.:Fr. f. sp. melonis (Leach \& Currence) W.C. Snyder \& H.N. Hans. causes Fusarium wilt of muskmelon (Cucumis melo L.) (17). This forma specialis has been divided into races based on pathogenicity to a set of differential cultivars within C. melo. Armstrong and Armstrong (2) classified F. oxysporum f. sp. melonis into seven races (races 1 through 7 ) based on six differential cultivars. Risser et al. (25) divided $F$. oxysporum f. sp. melonis into four races (races $0,1,2$, and 1,2) based on three differential cultivars. The classification system of Risser et al. (25) generally has been accepted rather than that of Armstrong and Armstrong (2), because the resistance genes effective against the respective races have been characterized in the differential cultivars. Muskmelon cvs. Charentais T, Doublon, and CM17187 were used by Risser et al. (25). Cvs. Doublon and CM17187 possess single dominant resistant genes, Fom1 and Fom2, respectively, and cv. Charentais T has no known resistance gene (25). The race nomenclature corresponds to the resistance genes that are overcome. Race 1,2 has been subdivided further into races $1,2 \mathrm{w}$ (wilt) and 1,2y (yellows) based on the symptoms they induce (5).

In Japan, a number of muskmelon cultivars have been bred and cultivated. Oriental melon (C. melo var. makuwa) and oriental pickling melon ( $C$. melo var. conomon) also have been cultivated. Oriental melon and oriental pickling melon are different from muskmelon in their geographic origin and their history of cultivation in Japan (20). Muskmelon was introduced from Europe $\approx 130$ years ago, whereas oriental melon and oriental pickling melon were introduced from China $\approx 1,500$ years ago.

Previously, we analyzed genetic similarity among strains of $F$. oxysporum causing wilts of cucurbits by DNA fingerprinting with

Corresponding author: F. Namiki; E-mail address: namikif@knaes.affrc.go.jp

Publication no. P-1998-0529-02R

(C) 1998 The American Phytopathological Society four repetitive DNA sequences: FOLR1 to FOLR4 (22). The analysis differentiated strains at the forma specialis level and detected two distinct genetic groups within $F$. oxysporum $\mathrm{f}$. sp. melonis. We tested the pathogenicity of 16 strains of $F$. oxysporum f. sp. melonis with muskmelon cvs. Amus and Homerun Star and oriental melon cvs. Ogon 9 and New Melon. The two genetic groups also differed in pathogenicity (22). One group caused wilts in both muskmelon and oriental melon cultivars, whereas the second group was pathogenic only to muskmelon cultivars. In 1989, Kobayashi (16) reported the occurrence of a new race of F. oxysporum f. sp. melonis in Kochi Prefecture, Japan. The race was identified as 1,2y based on Risser's classification system (16). In 1994, Fusarium wilt of muskmelon caused by similar strains of $F$. oxysporum $\mathrm{f}$. sp. melonis occurred in Hokkaido (10). An understanding of the occurrence and distribution of such pathogenic variants is important for developing effective methods of disease management, but only limited surveys have been conducted.

In this study, 41 strains of $F$. oxysporum $\mathrm{f}$. sp. melonis were collected from different locations in Japan and characterized for pathogenic variation, using muskmelon cvs. Charentais T, Doublon, CM17187, Amus, and Ohi and oriental melon cv. Ogon 9. Pathogenicity on 42 additional muskmelon, oriental melon, and oriental pickling melon cultivars also was examined. Furthermore, genetic similarity among strains was estimated based on FOLR DNA fingerprint comparisons. We found that races of $F$. oxysporum f. sp. melonis in Japan were differentiated at the DNA level by FOLR DNA fingerprinting, and there were intrarace, pathogenic variations that were not correlated with molecular variation detected by repetitive elements.

\section{MATERIALS AND METHODS}

Fungal strains and plant cultivars. The strains of $F$. oxysporum f. sp. melonis used in this study are listed in Table 1. These 
strains were collected from the 14 prefectures that are the major melon-growing areas in Japan (Table 1 and Fig. 1). All strains were obtained from single spores and maintained on potato dextrose agar.

Japanese muskmelon cvs. Amus and Ohi and oriental melon cv. Ogon 9 were used for pathogenicity tests of $F$. oxysporum f. sp. melonis strains, because we previously found that these cultivars were useful in identifying pathogenic variants within this forma specialis (22). For race classification, differential muskmelon cvs. Charentais T, Doublon, and CM17187 were used as reported by Risser et al. (25). Additionally, 28 muskmelon, 6 oriental melon, and 8 oriental pickling melon cultivars were employed to detect pathogenic variants within the forma specialis and races.

Pathogenicity tests. Each strain was grown in $100 \mathrm{ml}$ of potato dextrose broth (PDB) in 300-ml Erlenmeyer flasks at $28^{\circ} \mathrm{C}$ for 5 days

\section{TABLE 1. Strains of Fusarium oxysporum f. sp. melonis used in this study}

\begin{tabular}{|c|c|c|c|}
\hline $\begin{array}{l}\text { Code } \\
\text { no. }\end{array}$ & Strain $^{\mathrm{a}}$ & Origin $^{b}$ & Source $^{c}$ \\
\hline 1 & Mel:1-0 & Unknown & NRIV \\
\hline 2 & Mel:2-0 & Fukuoka & TVRS \\
\hline 3 & Mel:3-0 & Shizuoka & KNRIV \\
\hline 4 & Mel:4-0 & Shizuoka & KNRIV \\
\hline 5 & Mel:5-0 & Shizuoka & TVRS \\
\hline 6 & Mel:9-0 & Kumamoto & KNRIV \\
\hline 7 & Mel:10-0 & Nara & KNRIV \\
\hline 8 & Mel:11-0 & Hokkaido & KNRIV \\
\hline 9 & Mel:12-0 & Hokkaido & KNRIV \\
\hline 10 & Mel:15-0 & Chiba & KNRIV \\
\hline 11 & Mel:21-0 & Fukuoka & KNRIV \\
\hline 12 & Mel:22-0 & Unknown & KNRIV \\
\hline 13 & Mel02005 (JCM9286) & Kumamoto & KPARC \\
\hline 14 & Mel02008 (JCM9287) & Kumamoto & KPARC \\
\hline 15 & Mel02010 (JCM9288) & Nagasaki & This study \\
\hline 16 & Mel02011 & Nagasaki & This study \\
\hline 17 & Mel02013 & Kumamoto & KPARC \\
\hline 18 & Mel02025 (JCM9289) & Kumamoto & KPARC \\
\hline 19 & Mel02026 & Ibaragi & IAES \\
\hline 20 & Me102027 & Shimane & SmAES \\
\hline 21 & Me102032 & Yamagata & YAES \\
\hline 22 & Mel02036 & Kochi & This study \\
\hline 23 & Mel02044 & Unknown & KNRIV \\
\hline 24 & Mel02065 (JCM9290) & Kochi & This study \\
\hline 25 & Mel02066 & Kochi & This study \\
\hline 26 & Me102067 & Kochi & This study \\
\hline 27 & 90T1SV-1 & Kagoshima & KAES \\
\hline 28 & $90 \mathrm{~T} 2 \mathrm{SV}-2$ & Kagoshima & KAES \\
\hline 29 & A2-1 & Shimane & SmAES \\
\hline 30 & B-1 & Kanagawa & ARIK \\
\hline 31 & B-2 & Kanagawa & ARIK \\
\hline 32 & $\mathrm{C}-1$ & Kanagawa & ARIK \\
\hline 33 & $\mathrm{C}-2$ & Kanagawa & ARIK \\
\hline 34 & G1-1 & Shimane & SmAES \\
\hline 35 & M-1 (K) & Kagoshima & NRIV \\
\hline 36 & M-1 (S) & Shizuoka & SzAES \\
\hline 37 & M-10 & Aichi & NRIV \\
\hline 38 & MM1-1 & Shimane & SmAES \\
\hline 39 & MT1-1 & Shimane & SmAES \\
\hline 40 & $\mathrm{~T} 1-1$ & Shimane & SmAES \\
\hline 41 & JPPAM 11 & Fukuoka & JPPA \\
\hline
\end{tabular}

${ }^{a}$ Representative strains have been deposited in the Japan Collection of Microorganisms (JCM). Accession numbers are shown in parentheses.

$\mathrm{b}$ The prefectures in Japan from which strains were collected.

${ }^{\mathrm{c}}$ NRIV = National Research Institute of Vegetables, Ornamental Plants and Tea (D. Ishiuchi); TVRS = Toyama Vegetable and Ornamental Crops Research Station (Y. Nomura); KNRIV = Kurume Branch of National Research Institute of Vegetables, Ornamental Plants and Teas (N. Kobayashi); KPARC = Kumamoto Prefecture Agricultural Research Center (K. Komaki); IAES = lbaragi Agricultural Experiment Station (K. Watanabe); SmAES = Shimane Agricultural Experiment Station (K. Hirosawa and T. Mikami); YAES = Yamagata Agricultural Experiment Station; KAES = Kagoshima Agricultural Experiment Station (S. Izumi); ARIK = Agricultural Research Institute of Kanagawa Prefecture; SzAES = Shizuoka Agricultural Experiment Station (T. Makino); and JPPA = Japan Plant Protection Association (H. Kiso). Donors of strains are shown in parentheses. on a reciprocal shaker (125 strokes per min). The resulting culture was passed through four layers of cheesecloth, and the filtrate was centrifuged at $2,000 \times g$ for $10 \mathrm{~min}$. The bud cell pellet was resuspended in distilled water to produce a concentration of $10^{7}$ cells per $\mathrm{ml}$. The pathogenicity of the strains used was assayed by a root-dip method (29). Seedlings were grown in soil sterilized with chloropicrin. Seedlings with fully expanded leaves were used for pathogenicity tests. The healthy seedlings were removed from the soil, and their roots were washed gently with water. The roots were dipped in a bud cell suspension for $15 \mathrm{~s}$; five plants were inoculated per strain. Inoculated seedlings were transplanted to plastic pots $(6 \mathrm{~cm}$ diameter) filled with sterilized soil and placed in a greenhouse $\left(25\right.$ to $\left.30^{\circ} \mathrm{C}\right)$. External symptoms and vascular discoloration were scored 21 days after inoculation, and the pathogen was reisolated from the vascular bundles of inoculated plants. Pathogenicity tests were conducted three times for all strains. We used three strains (Mel02005, Mel02010, and Mel02065) from three races together with test strains in each set of pathogenicity tests as controls to check plant response.

DNA manipulation. Fungal strains were grown in $200 \mathrm{ml}$ of PDB in 1-liter Roux bottles at $28^{\circ} \mathrm{C}$ for 4 days. The resulting mycelia were ground in liquid nitrogen in a mortar with a pestle. Total cellular DNA was prepared from the powdered mycelia by the method of Adachi et al. (1).

Four genomic clones (FOLR1 to FOLR4) were used as hybridization probes to examine genetic variation within $F$. oxysporum $\mathrm{f}$. sp. melonis. FOLR clones were selected from a genomic library of F. oxysporum f. sp. lagenariae strain MAFF 305118 (22). The FOLR clones were characterized; they carried moderately repetitive DNA sequences dispersed in the fungal chromosomes (22). Recombinant $\lambda$-phage DNA was isolated by the plate lysate method (27).

Fungal DNA was digested to completion with EcoRV and separated by electrophoresis in $0.8 \%$ agarose gels by standard methods (27). The fractionated DNA was transferred to Hybond N+ nylon membranes (Amersham Corp., Arlington Heights, IL) by the alkaline transfer method (24). DNA probes were labeled with $\left[\alpha-{ }^{32} \mathrm{P}\right] \mathrm{dCTP}$ (ICN Biochemicals Inc., Costa Mesa, CA) by the random-primer method (8). Hybridization was carried out in $5 \times$ SSPE $(1 \times$ SSPE is $180 \mathrm{mM} \mathrm{NaCl}, 10 \mathrm{mM}$ sodium phosphate [pH 7.7], and $1 \mathrm{mM}$ EDTA) containing $5 \times$ Denhardt's solution (27), $0.5 \%$ sodium dodecyl sulfate (SDS), $100 \mu \mathrm{g}$ of sonicated salmon sperm DNA per $\mathrm{ml}$, and $50 \%$ formamide at $42^{\circ} \mathrm{C}$. Hybridized blots were washed at $65^{\circ} \mathrm{C}$, with the final wash in $1 \times$ SSPE and $0.1 \%$ SDS. Hybridization signals were detected by exposing mem-

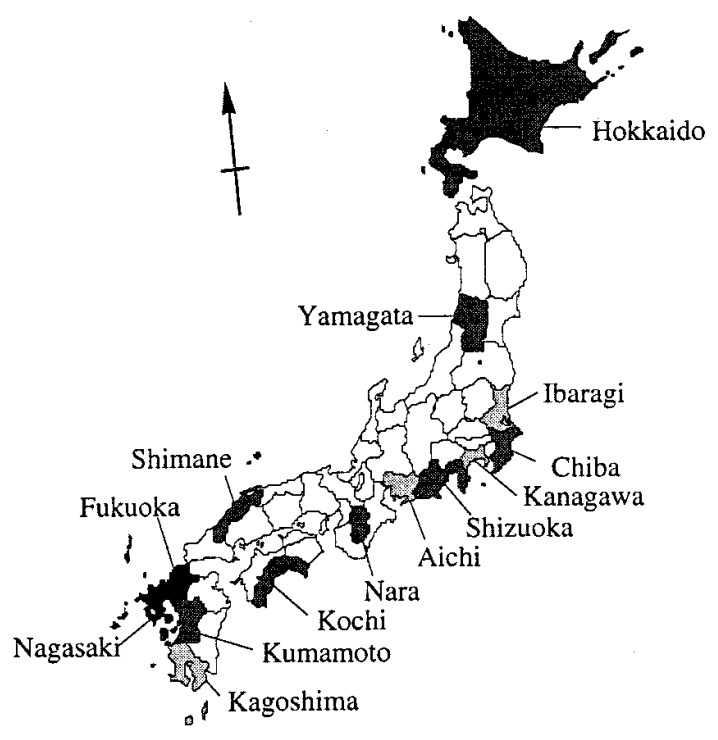

Fig. 1. Locations of prefectures in Japan from which strains of Fusarium oxysporum f. sp. melonis were collected. Arrow indicates north. 
branes to X-ray film (X-OMAT, Eastman Kodak Co., Rochester, NY) for 2 to 3 days at room temperature without an intensifying screen.

Data analysis. The pathogenicity data for 41 strains to 33 muskmelon, 7 oriental melon, and 8 oriental pickling melon cultivars were used to measure the similarity within the forma specialis and races. The pathogenicity of each strain was scored as either 1 or 0 , which corresponds to the pathogenic or nonpathogenic phenotype, respectively, of each of 48 cultivars. The FOLR DNA fingerprint profiles also were used to measure genetic similarity among strains. Each band with a different electrophoretic mobility was assigned a position number and scored as either 1 or 0 based on the presence or absence of the band, respectively, for this position. The similarity coefficient for all possible pairs of strains based on their pathogenicity and fingerprints was estimated by the method of Nei and $\mathrm{Li}$ (23). Dendrograms were constructed from the similarity coefficient data by the unweighted pair group method with arithmetic average (UPGMA) clustering (28).

To evaluate the robustness of the groupings formed, the binary data set was subjected to bootstrapping. Using the WinBoot software program (30), the phenogram was reconstructed 2,000 times by repeated sampling with replacement, and the frequency with which a particular group was formed reflected the strength of the group. To compare the relationship between clusters formed by pathogenicity and DNA data, the correlation between the two similarity matrixes was estimated by the MXCOMP program in NTSYSpc, version 2.00 (26).

\section{RESULTS}

Race classification of Japanese strains of $\boldsymbol{F}$. oxysporum $\mathbf{f}$. sp. melonis. Japanese muskmelon (Amus and Ohi) and oriental melon (Ogon 9) cultivars were used for pathogenicity tests of Japanese strains of $F$. oxysporum f. sp. melonis. The 41 strains collected from various locations in Japan were classified into three groups on the basis of differences in pathogenicity to these cultivars (Table 2). Strains of group I (code numbers 24 through 26) were pathogenic to all three cultivars. Although cv. Ohi is resistant to Fusarium wilt of muskmelon and has been used as the stock for grafting cultures in Japan, strains of group I were pathogenic to this cultivar. Strains of group II (code numbers 1, 2, 5, 7, 12, 15, 16, 19 through 21, 30 through 35, and 38 through 41) were pathogenic to muskmelon cv. Amus and oriental melon cv. Ogon 9 but not to muskmelon cv. Ohi. Strains of group III (code numbers 3, 4, 6, 8 through 11, 13, 14, 17, 18, 22, 23, 27 through 29, 36, and 37) were pathogenic only to muskmelon cv. Amus. These results indicate that at least three pathogenic groups occur in the Japanese population of F. oxysporum f. sp. melonis.

TABLE 2. Race classification of Japanese strains of Fusarium oxysporum f. sp. melonis

\begin{tabular}{lccccc}
\hline & \multicolumn{3}{c}{ Pathogenicity $^{\mathrm{a}}$} & & \\
\cline { 2 - 4 } Code no. & $\begin{array}{c}\text { Amus and } \\
\text { Charentais T }\end{array}$ & $\begin{array}{c}\text { Ohi and } \\
\text { Doublon }\end{array}$ & $\begin{array}{c}\text { Ogon 9 and } \\
\text { CM17187 }\end{array}$ & $\begin{array}{c}\text { Pathogenic } \\
\text { group }\end{array}$ & Race \\
\hline $3,4,6,8-11$, & + & - & - & III & 0 \\
$13,14,17$, \\
$18,22,23$,
\end{tabular}

The $41 F$. oxysporum f. sp. melonis strains were subjected to race classification, using three differential cultivars: Charentais $\mathrm{T}$, Doublon, and CM17187 (25). Three pathogenic groups classified with Japanese muskmelon and oriental melon cultivars correlated with three races. Strains of group I were identified as race $1,2 \mathrm{y}$ : they caused yellows as an early symptom and finally death in all the differential cultivars. Strains of group II were classified as race 2: they were pathogenic to Charentais $\mathrm{T}$ and $\mathrm{CM} 17187$ but not to Doublon. Strains of group III were classified as race 0: they were pathogenic only to Charentais $\mathrm{T}$. These results indicate the usefulness of these Japanese muskmelon and oriental melon cultivars for race classification of $F$. oxysporum $\mathrm{f}$. sp. melonis.

Strains of races 0 and 2 both were detected in samples from 9 of 14 prefectures from which strains were collected, indicating these races are widely distributed in Japan. In contrast, strains of race $1,2 \mathrm{y}$ were found only in samples from Kochi Prefecture, suggesting a restricted distribution of this race in Japan.

TABLE 3. Pathogenicity of strains from three races of Fusarium oxysporum f. sp. melonis on melon, oriental melon, and oriental pickling melon cultivars

\begin{tabular}{|c|c|c|c|}
\hline \multirow{2}{*}{$\begin{array}{l}\text { Plant } \\
\text { Cultivar }\end{array}$} & \multicolumn{3}{|c|}{ Pathogenicity $^{\mathrm{a}}$} \\
\hline & Race 0 & Race 2 & Race $1,2 y$ \\
\hline \multicolumn{4}{|l|}{ Muskmelon } \\
\hline Andes & - & - & + \\
\hline Aswan & - & - & + \\
\hline Base & - & - & + \\
\hline Cossack & $+/-$ & + & + \\
\hline Crest spring-autumn & - & - & + \\
\hline Crest autumn-winter & - & - & + \\
\hline Earl's Cenu Spring I & - & - & + \\
\hline Earl's Cenu Summer I & - & - & + \\
\hline Earl's Favorite Harukei & $+/-$ & $+/-$ & + \\
\hline Earl's Knight Natsu No. 1 & - & - & + \\
\hline Earl's Tokai EG360 & - & - & + \\
\hline Earl's Tokai PF80 & - & - & + \\
\hline Earl's Tokai R210 & - & - & + \\
\hline Earl's Tokai R230 & - & - & + \\
\hline Enken Daigi 2 & - & - & + \\
\hline Fukamidori & - & - & + \\
\hline Homerun Star & + & + & + \\
\hline Honey Dew PF & - & - & + \\
\hline Kenkyaku & - & - & + \\
\hline Kongo 1 & - & - & + \\
\hline Kyouei & - & - & + \\
\hline Melon Partner & - & - & + \\
\hline Ohi Shin 1 & - & - & + \\
\hline Papaya Melon & $+/-$ & $+1-$ & + \\
\hline Shinju & - & - & + \\
\hline Shinju 100 & - & - & + \\
\hline Sun Rise & + & + & + \\
\hline US 1 & - & - & + \\
\hline \multicolumn{4}{|l|}{ Oriental melon } \\
\hline Corona & - & + & + \\
\hline Ginsen & - & + & + \\
\hline Kinmei & - & $+1-$ & + \\
\hline Kintaro & - & + & + \\
\hline New Melon & - & + & + \\
\hline Ohgata Kikumelon & - & + & + \\
\hline \multicolumn{4}{|l|}{ Oriental pickling melon } \\
\hline Ao Ohnaga Shimauri & - & + & + \\
\hline Awamidori & - & + & + \\
\hline Katsura Ohshirouri & - & + & + \\
\hline Nagasaki Tsukeuri & + & + & + \\
\hline Sanuki Shirouri & - & + & + \\
\hline Shirohagura & - & + & + \\
\hline Tokyo Ohshirouri & - & + & + \\
\hline Yokauri & - & + & + \\
\hline
\end{tabular}

a To test for pathogenicity, each strain was inoculated to 15 seedlings of each cultivar. Pathogenic strains caused external symptom and vascular discoloration on 5 to 15 seedlings per 15 seedlings inoculated. Nonpathogenic strains caused no visible symptoms on seedlings. $+=$ pathogenic; $-=$ nonpathogenic $;+/-=$ pathogenic or nonpathogenic, depending on strain. 
Pathogenic variation within races of $F$. oxysporum $f$. sp. melonis. To further characterize pathogenic variation within the forma specialis and races, strains were tested for pathogenicity to additional muskmelon, oriental melon, and oriental pickling melon cultivars $(28,6$, and 8 , respectively) (Table 3$)$. All strains of race 0 were pathogenic to two muskmelon cultivars and one oriental pickling melon cultivar but not to any oriental melon cultivars. Pathogenic variation within race 0 was detected with three muskmelon cultivars (Earl's Favorite Harukei, Cossack, and Papaya melon), and the strains were classified into six pathogenic variants: A through F (Table 4). Among 18 strains of race 0,3 caused wilts in all three cultivars, but the remaining 15 strains were different in pathogenicity to three cultivars (Table 4). All strains of race 2 were pathogenic to the three muskmelon, five oriental melon, and all oriental pickling melon cultivars. Pathogenic variation within race 2 was observed with two muskmelon cultivars (Earl's Favorite Harukei and Papaya melon) and an oriental melon cultivar (Kinmei), and the strains were divided into six pathogenic variants: A through $\mathrm{F}$ (Table 4). Among 20 strains of race 2, 14 were pathogenic to all three cultivars, but the remaining 6 strains were different in pathogenicity to three cultivars (Table 4). In contrast, strains of race $1,2 y$ were pathogenic to all cultivars examined.

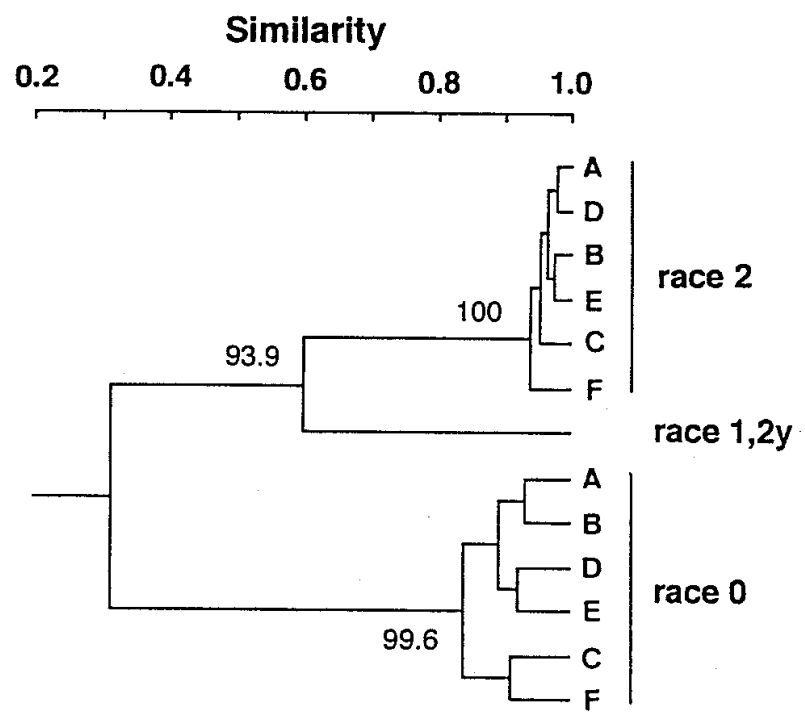

Fig. 2. Dendrogram showing the levels of similarity among races and pathogenic variants of Fusarium oxysporum f. sp. melonis. The 41 strains were divided into races 0,2 , and $1,2 \mathrm{y}$, and races 0 and 2 each were divided further into 6 pathogenic variants on the basis of pathogenicity to 48 melon cultivars (Tables 2 and 3). Similarity coefficients were calculated from pathogenicity data by the method of Nei and $\mathrm{Li}$ (23). A dendrogram was constructed from the similarity coefficients, using the unweighted pair group method with arithmetic average clustering (28). Values on the branches of the clusters represent the results of bootstrap analysis (the percentage of times the group occurred during 2,000 iterations). Bootstrap analysis was performed by the WinBoot software program (30). Pathogenic variants (Table 4) are indicated to the right.
The similarity coefficients between races and pathogenic variants were measured by cluster analysis of the pathogenicity data shown in Tables 2 and 3, and a dendrogram was constructed using UPGMA (Fig. 2). The dendrogram identified three races. Bootstrap analysis showed that three clusters (corresponding to race classification) were robust: each was formed in 93.9 to $100 \%$ of the 2,000 iterations (Fig. 2). Pathogenic variants within races 0 and 2 were placed into clusters in their respective races.

Genetic similarity among strains of $F$. oxysporum f. sp. melonis. To assess genetic similarity among the $41 F$. oxysporum $\mathrm{f}$. sp. melonis strains, DNA fingerprinting with four repetitive sequences (FOLR1 to FOLR4) were conducted. Total DNA of each strain was digested with EcoRV and hybridized with ${ }^{32} \mathrm{P}$-labeled FOLR probes. FOLR1 to FOLR4 probes hybridized to 12 to 29,8 to 18 , 5 to 33, and 6 to 21 EcoRV fragments, respectively, in each of the 41 strains. Each probe produced different DNA fingerprints within single races. As an example, Southern blots of 41 strains produced with the FOLR3 probe are shown in Figure 3. FOLR3 DNA fingerprinting clearly divided strains into four groups corresponding to races: 20 strains (code numbers 1, 2, 5, 7, 12, 15, 16, 19 through 21,30 through 35 , and 38 through 41 ) of race $2 ; 14$ strains (code numbers $3,4,6,11,13,14,17,18,22,23,27$ through 29, and 37) of race $0 ; 4$ strains (code numbers 8 through 10 and 36 ) of race 0 ; and 3 strains (code numbers 24 through 26) of race 1,2y. Strains of race 0 were divided into two groups.

DNA fingerprinting of the 41 strains with FOLR1 to FOLR4 probes produced $32,34,32$, and 32 fingerprint types, respectively. By pooling results from the four FOLR probes, the 41 strains were designated as 36 fingerprint types. We used all DNA fingerprints with four FOLR probes to measure the genetic similarity among strains by cluster analysis. A total of 149 resolvable fragments were found in the 41 strains by pooling the results of fingerprinting with four FOLR probes. The similarity coefficients between the fingerprint types were calculated, and a dendrogram was constructed using UPGMA (Fig. 4). The dendrogram identified four genetic groups that corresponded to race classification. Bootstrap analysis showed that four clusters were robust: each was formed in 65.8 to $100 \%$ of the 2,000 iterations (Fig. 4). Strains of race 2 clustered in a single group, but the similarity level among strains was not high. Strains of race $1,2 \mathrm{y}$ clustered in a single group and were closely related to one another, but the clustering may have been due to a limited sample. In contrast, strains of race 0 were divided into two genetic groups. The geographic origin of strains seemed not to correlate with genetic similarity. Pathogenic variants within races 0 and 2 were detected by pathogenicity tests with 42 cultivars (Tables 3 and 4). Based on the dendrogram, strains of different pathogenic variants were grouped into a single cluster and, in some cases, were more closely related than strains of the same pathogenic variant (Fig. 4). Thus, these pathogenic variants within races could not be differentiated from one another by FOLR DNA fingerprinting. This result was confirmed by comparison of the two similarity matrixes generated by pathogenicity and DNA fingerprint data: the matrix correlation was low $(r=0.47)$.

TABLE 4. Pathogenic variants within races 0 and 2 of Fusarium oxysporum f. sp. melonis

\begin{tabular}{|c|c|c|c|c|c|c|c|c|c|c|c|c|}
\hline \multirow{3}{*}{$\begin{array}{l}\text { Plant } \\
\text { Cultivar }\end{array}$} & \multicolumn{12}{|c|}{ Pathogenicity ${ }^{\mathrm{a}}$} \\
\hline & \multicolumn{6}{|c|}{ Race 0 variant } & \multicolumn{6}{|c|}{ Race 2 variant } \\
\hline & A & B & $\mathrm{C}$ & $\mathrm{D}$ & E & F & A & B & $\mathrm{C}$ & $\mathrm{D}$ & E & $\mathrm{F}$ \\
\hline Earl's Favorite Harukei & + & + & + & - & - & - & + & + & - & - & - & - \\
\hline Cossack & + & - & - & + & - & - & + & + & + & + & + & + \\
\hline Papaya Melon & + & + & - & + & + & - & + & + & - & + & + & - \\
\hline Number of strains & 3 & 8 & 1 & 2 & 2 & 2 & 14 & 1 & 2 & 1 & 1 & 1 \\
\hline
\end{tabular}

a $+=$ pathogenic $;-=$ nonpathogenic . 

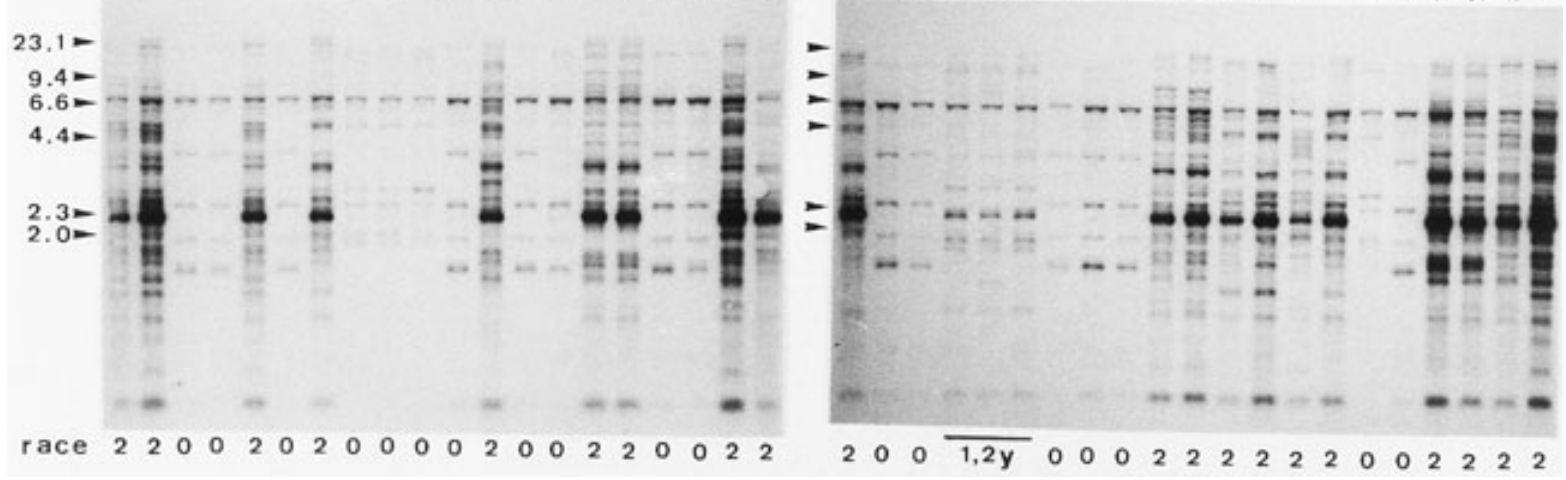

Fig. 3. Clone FOLR3 DNA fingerprints of 41 strains of Fusarium oxysporum f. sp. melonis. Total DNA was digested with EcoRV and fractionated on $0.8 \%$ agarose gel. The Southern blots were hybridized with ${ }^{32} \mathrm{P}-$ labeled FOLR3 DNA. The numbers above lanes indicate strain code numbers (Table 1). The sizes of marker DNA fragments (HindIII-digested $\lambda$ DNA) are indicated to the left in kilobases.

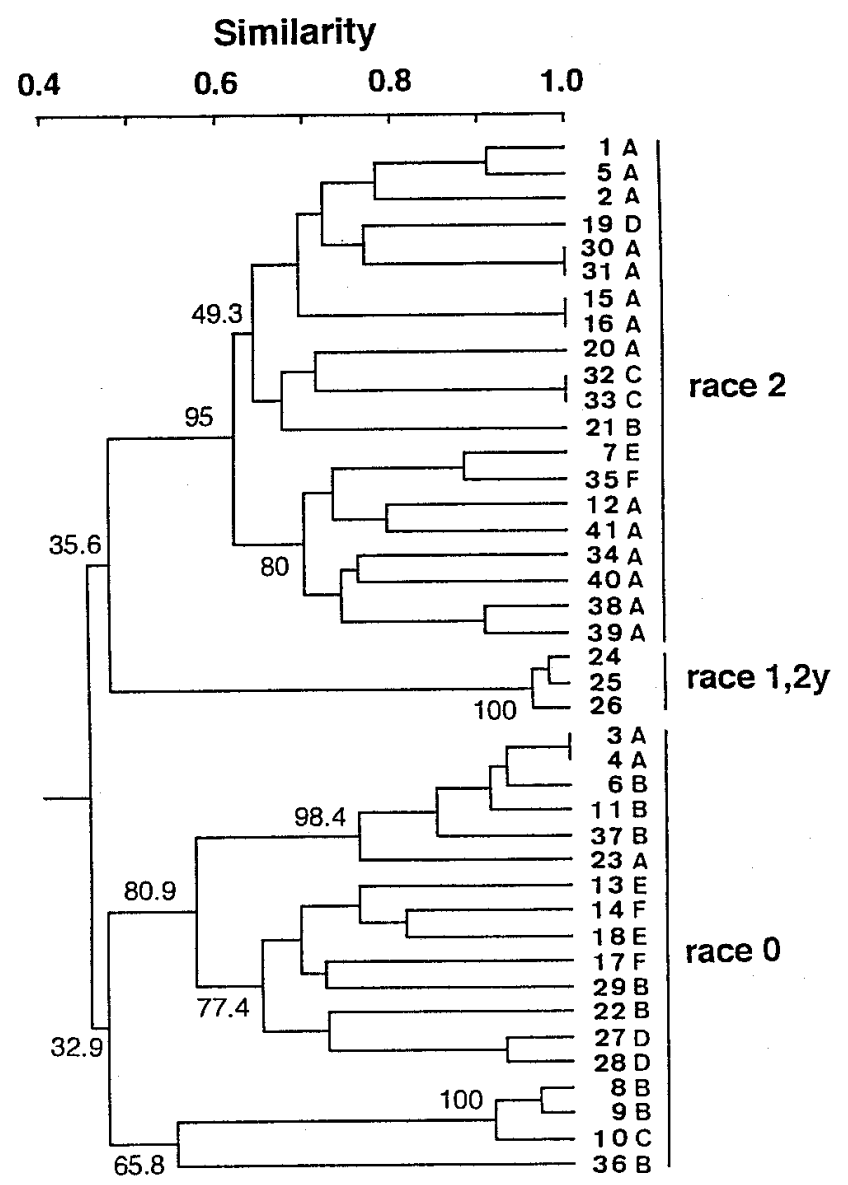

Fig. 4. Dendrogram showing the levels of genetic relatedness among 41 strains of Fusarium oxysporum f. sp. melonis. The 41 strains were divided into 36 fingerprint types on the basis of fingerprints probed with clones FOLR1 through FOLR4. Similarity coefficients were calculated based on the fingerprints by the method of Nei and $\mathrm{Li}(23)$. A dendrogram was constructed from the similarity coefficients, using the unweighted pair group method with arithmetic average clustering (28). Values on the branches of the clusters represent the results of bootstrap analysis (the percentage of times the group occurred during 2,000 iterations). Bootstrap analysis was performed by the WinBoot software program (30). Strain code numbers (Table 1) and pathogenic variants (Table 4) are indicated to the right.

\section{DISCUSSION}

The classification system of races within $F$. oxysporum f. sp. melonis proposed by Risser et al. (25) generally has been accepted. However, it is difficult to routinely use this system for Japanese strains, because seeds of the race differential cultivars are not commercially available in Japan. In this study, we found Japanese cultivars that could substitute for the race differential cultivars used by Risser et al. (25). Using muskmelon cvs. Amus and Ohi and oriental melon cv. Ogon 9, 41 Japanese strains were characterized as race 0,2 , or 1,2y. Cvs. Amus, Ohi, and Ogon 9 showed the same reactions to strains as those shown by differential cultivars Charentais T, Doublon, and CM17187, respectively. These results suggest that Ohi and Ogon 9 possess resistance genes similar in function to Foml of Doublon and Fom2 of CM17187, respectively, although the resistance genes of Ohi and Ogon 9 have not been defined genetically. Race 1 was not detected in our sample and has not been reported from Japan.

To detect further pathogenic variation within the races, we used 42 additional muskmelon, oriental melon, and oriental pickling melon cultivars for pathogenicity assays. Use of these cultivars divided race 0 strains into six variants that differed in pathogenicity to three muskmelon cultivars. Race 2 strains also were classified into six variants based on differences in pathogenicity to two muskmelon cultivars and one oriental melon cultivar. Pathogenic variants within races 0 and 2 were placed into clusters in their respective races in a dendrogram based on pathogenicity to 48 cultivars, including race differential cultivars. These results indicate that races 0 and 2 contain pathogenic variation. As far as we know, intrarace, pathogenic variation has not been reported previously in F. oxysporum f. sp. melonis.

All strains of race $1,2 \mathrm{y}$ were pathogenic to all cultivars. Race 1,2y was first detected in Japan in 1984 in Kochi Prefecture (16). The prevalence of race $1,2 \mathrm{y}$ caused severe damage in this prefecture, because all previously used cultivars were susceptible to this new race (16). In 1994, Fusarium wilt of muskmelon caused by similar strains also occurred in Hokkaido (10). Until now, the prevalence of such strains has been limited to these two locations in Japan. These strains have the potential to cause serious problems in muskmelon production in Japan, because an effective source of resistance to this race has not been found.

Namiki et al. (22) previously showed that DNA fingerprinting could differentiate the formae speciales of $F$. oxysporum causing wilts of cucurbits and also races within $F$. oxysporum f. sp. melonis. On the basis of FOLR fingerprint profiles, 41 strains were distinguishable. A dendrogram was constructed based on cluster analysis of similarity coefficients, using UPGMA. Each population of races 2 and 1,2y grouped into single clusters. Strains of race 0 were divided into two distinct groups. In contrast, pathogenic variants within races 0 and 2 could not be differentiated by cluster analysis based on FOLR DNA fingerprinting. None of these pathogenic variants clustered on the dendrogram: in some cases, strains of different pathogenic variants were more similar genetically than strains of the same pathogenic variant. These results suggest that 
the Japanese populations of $F$. oxysporum f. sp. melonis contain pathogenic variants within races not distinguished by DNA fingerprinting. The pathogenic variants may have originated through simple, recent mutations within populations of races 0 and 2 .

Restriction fragment length polymorphisms (RFLPs) of nuclear and mitochondrial DNA (mtDNA) have been used to characterize genetic variation within and among the formae speciales of $F$. oxysporum, including $F$. oxysporum f. sp. melonis $(3,4,7,9,11-15,18$, $19,21,22)$. Most studies failed to show a positive correlation between pathogenic variation and DNA polymorphisms $(4,7,9,11-$ $14,18,19,21)$. Jacobson and Gordon (11) analyzed vegetative compatibility groups (VCGs) and mtDNA RFLPs of $F$. oxysporum $\mathrm{f}$. sp. melonis strains collected from Europe, the Middle East, and the United States. Their analysis showed that RFLP patterns of mtDNA corresponded with VCGs but not with races (11). Kim et al. (14) demonstrated a close relationship among different formae speciales on cucurbits based on RFLPs of mtDNA of strains collected from the United States and a few other countries. These results suggest that pathogenicity has evolved independently of mtDNA at a different rate $(6,7,9,11,12,14)$.

On the other hand, studies reported that random amplified polymorphic DNA analysis could separate strains of $F$. oxysporum f. sp. vasinfectum into three genetic groups corresponding to races A, 3 , and $4(3,9)$. These three races of $F$. oxysporum f. sp. vasinfectum were classified on the basis of pathogenicity to three differential cotton species (Gossypium hirsutum, G. barbadense, and G. arboreum) (9). Geographic distribution is distinctly different among these races. Race A occurs in the United States and most African countries; race 3 occurs in Egypt, Sudan, and Israel; and race 4 occurs in India, China, and Uzbekistan (9). Thus, it is proposed that genetic differentiation of the races might be attributed to the wide host range of $F$. oxysporum $\mathrm{f}$. sp. vasinfectum and to the geographical separation of the races $(3,9)$.

In this study, we showed that the Japanese strains of $F$. oxysporum f. sp. melonis could be distinguished at the race level by FOLR DNA fingerprinting. Such relationships between pathogenic and genetic variation might be a characteristic of the Japanese population, which probably has been isolated geographically from populations of other countries. Limited introduction of inocula from other countries may have led to a simple pathogen population structure. Thus, our results suggest that the Japanese strains within single races are derivatives of one or a few clonal ancestors. However, the lack of relationship between intrarace pathogenic variation and DNA fingerprints suggests that the evolution of pathogenic variation is faster than genomic changes, as inferred by the four repetitive elements.

We are now testing the pathogenicity of strains collected from other countries with Japanese muskmelon, oriental melon, and oriental pickling melon cultivars and are analyzing genetic similarity between strains collected from Japan and other countries based on FOLR DNA fingerprinting. These studies will provide a basis for evaluating the evolution of pathogenic specialization in $F$. oxysporum, taking into account the impact of geographic isolation and coevolution with host plants.

\section{ACKNOWLEDGMENTS}

This work was supported by a grant-in-aid for special scientific research on agriculture, forestry, and fisheries from the Ministry of Agriculture, Forestry and Fisheries of Japan. We thank T. R. Gordon for critical review of the manuscript and for providing seeds of race differential cultivars, G. Risser for providing seeds of the race differential cultivars, R. J. Nelson for the computer program WinBoot, K. Satoh for increasing the seeds, and A. Fujii for technical assistance.

\section{LITERATURE CITED}

1. Adachi, Y., Watanabe, H., Tanabe, K., Doke, N., Nishimura, S., and Tsuge, T. 1993. Nuclear ribosomal DNA as a probe for genetic variability in the
Japanese pear pathotype of Alternaria alternata. Appl. Environ. Microbiol. 59:3197-3205.

2. Armstrong, G. M., and Armstrong, J. K. 1978. Formae speciales and races of Fusarium oxysporum causing wilts of the Cucurbitaceae. Phytopathology 68:19-28.

3. Assigbetse, K. B., Fernandez, D., Dubois, M. P., and Geiger, J. P. 1994. Differentiation of Fusarium oxysporum $\mathrm{f}$. sp. vasinfectum races on cotton by random amplified polymorphic DNA (RAPD) analysis. Phytopathology 84:622-626.

4. Bødker, L., Lewis, B. G., and Codington, A. 1993. The occurrence of a new genetic variant of Fusarium oxysporum f. sp. pici. Plant Pathol. 42: 833-838.

5. Bouhot, D. 1981. Some aspects of the pathogenic potential in formae speciales and races of Fusarium oxysporum on Cucurbitaceae. Pages 318-326 in: Fusarium: Disease, Biology, and Taxonomy. P. E. Nelson, T. A. Toussoun, and R. J. Cook, eds. The Pennsylvania State University Press, University Park.

6. Bruns, T. D., White, T. J., and Taylor, J. W. 1991. Fungal molecular systematics. Annu. Rev. Ecol. Syst. 22:525-564.

7. Elias, K. S., Zamir, D., Lichtman-Pleban, T., and Katan, T. 1993. Population structure of Fusarium oxysporum f. sp. lycopersici: Restriction fragment length polymorphisms provide genetic evidence that vegetative compatibility group is an indicator of evolutionary origin. Mol. PlantMicrobe Interact. 6:565-572.

8. Feinberg, A. P., and Vogelstein, B. 1983. A technique for radiolabeling DNA restriction endonuclease fragments to high specific activity. Anal. Biochem. 132:6-13.

9. Fernandez, D., Assigbetse, K., Dubois, M. P., and Geiger, J. P. 1994. Molecular characterization of races and vegetative compatibility groups in Fusarium oxysporum f. sp. vasinfectum. Appl. Environ. Microbiol. 60: 4039-4046.

10. Iwata, Y., Tamura, O., and Sumino, A. 1994. Occurrence of Fusarium wilt of melon caused by Fusarium oxysporum f. sp. melonis which shows different symptoms and parasitism in Hokkaido. Annu. Rep. Plant Prot. North. Jpn. 45:62-68. (In Japanese)

11. Jacobson, D. J., and Gordon, T. R. 1990. Variability of mitochondrial DNA as an indicator of relationships between populations of Fusarium oxysporum f. sp. melonis. Mycol. Res. 94:734-744.

12. Jacobson, D. J., and Gordon, T. R. 1991. Fusarium oxysporum f. sp. melonis: A case study of diversity within a forma specialis. Phytopathology 81:1064-1067.

13. Kelly, A., Alcalá-Jiménez, A. R., Bainbridge, B. W., Heale, J. B., PérezArtés, E., and Jiménez-Díaz, R. M. 1994. Use of genetic fingerprinting and random amplified polymorphic DNA to characterize pathotypes of Fusarium oxysporum f. sp. ciceris infecting chickpea. Phytopathology 84: 1293-1298.

14. Kim, D. H., Martyn, R. D., and Magill, C. W. 1993. Mitochondrial DNA (mtDNA)-Relatedness among formae speciales of Fusarium oxysporum in the Cucurbitaceae. Phytopathology 83:91-97.

15. Kistler, H. C., Momol, E. A., and Benny, U. 1991. Repetitive genomic sequences for determining relatedness among strains of Fusarium oxysporum. Phytopathology 81:331-336.

16. Kobayashi, T. 1989. Soilborne disease in Kochi Prefecture. The Phytopath. Soc. Jpn. Soilborne Dis. Workshop Rep. 14:1-5. (In Japanese)

17. Leach, J. G., and Currence, T. M. 1938. Fusarium wilt of muskmelon in Minnesota. Minn. Agric. Exp. Stn. Tech. Bull. 129:32.

18. Manicom, B. Q., Bar-Joseph, M., Kotze, J. M., and Becker, M. M. 1990. A restriction fragment length polymorphism probe relating vegetative compatibility groups and pathogenicity in Fusarium oxysporum f. sp. dianthi. Phytopathology 80:336-339.

19. Manicom, B. Q., Bar-Joseph, M., Rosner, A., Vigodsky-Haas, H., and Kotze, J. M. 1987. Potential applications of random DNA probes and restriction fragment length polymorphisms in the taxonomy of the fusaria. Phytopathology 77:669-672.

20. Matsuo, T., ed. 1989. Collected Data of Plant Genetic Resources, vol. 2. Kodansya Scientific Publisher, Tokyo.

21. Mes, J. J., Van Doorn, J., Roebroeck, E. J. A., Van Egmond, E., Van Aartrijk, J., and Boonekamp, P. M. 1994. Restriction fragment length polymorphisms, races and vegetative compatibility groups within a worldwide collection of Fusarium oxysporum f. sp. gladioli. Plant Pathol. 43: 362-370.

22. Namiki, F., Shiomi, T., Kayamura, T., and Tsuge, T. 1994. Characterization of the formae speciales of Fusarium oxysporum causing wilts of cucurbits by DNA fingerprinting with nuclear repetitive DNA sequences. Appl. Environ. Microbiol. 60:2684-2691.

23. Nei, M., and Li, W. H. 1979. Mathematical model for studying genetic variation in terms of restriction endonucleases. Proc. Natl. Acad. Sci. USA 76:5269-5273

24. Reed, K. C., and Mann, D. A. 1985. Rapid transfer of DNA from agarose 
gels to nylon membranes. Nucleic Acids Res. 13:7207-7221.

25. Risser, G., Banihashemi, Z., and Davis, D. W. 1976. A proposed nomenclature of Fusarium oxysporum f. sp. melonis races and resistance genes in Cucumis melo. Phytopathology 66:1105-1106.

26. Rohlf, F. J. 1997. NTSYSpc: Numerical Taxonomy and Multivariate Analysis System Version 2.00 User Guide. Exeter Software, Setauket, NY.

27. Sambrook, J., Fritsch, E. F., and Maniatis, T. 1989. Molecular Cloning: A Laboratory Manual. 2nd ed. Cold Spring Harbor Laboratory Press, Cold Spring Harbor, NY.
28. Sneath, P. H. A., and Sokal, R. R. 1973. Numerical Taxonomy: The Principles and Practice of Numerical Classification. W. H. Freeman \& Co., San Francisco.

29. Wellman, F. L. 1939. A technique for studying host resistance and pathogenicity in tomato Fusarium wilt. Phytopathology 29:945-956.

30. Yap, I., and Nelson, R. J. 1996. WinBoot: A program for performing bootstrap analysis of binary data to determine the confidence limits of UPGMAbased dendrograms. IRRI Discus. Pap. Ser. 14. International Rice Research Institute, Manila, Philippines. 